\title{
Efektivitas Media Pembelajaran Video Pada Model Pembelajaran Virtual Mata Kuliah Strategi Belajar Mengajar di Prodi PTIK JTIK Fakultas Teknik Universitas Negeri Makassar
}

\author{
Nurhuda ${ }^{1}$, Riana T Mangesa ${ }^{2}$, Muh Nasir Malik \\ Pendidikan Teknik Informatika dan Komputer, Universitas Negeri Makassar \\ ${ }^{1}$ nurhudaramangegmail.com \\ ${ }^{2}$ Rianamangesa@yahoo.com
}

\begin{abstract}
Abstrak - Penelitian ini bertujuan untuk mengetahui: (1) Efektivitas media pembelajaran video pada model pembelajaran virtual efektifi dipergunakan mata kuliah Strategi Belajar Mengajar di Prodi PTIK JTIK FT Universitas Negeri Makassar; (2) Terjadi Peningkatan aktivitas belajar peserta didik dengan media pembelajaran video pada model pembelajaran virtual di Prodi PTIK JTIK FT Universitas Negeri Makassar. Penelitian ini merupakan penelitian Quasi-experiment dengan desain Pretest-Posttest Control Group Design. Populasi penelitian ini adalah mahasiswa PTIK yang mengikuti pelajaran Strategi Belajar Mengajar. Sampel diambil dengan menggunakan purposive sampling, yakni 2 kelompok, kelompok A (Kelas PTIK C) dan kelompok B (Kelas PTIK E). Teknik pengumpulan data menggunakan instrumen digital melalui angket, observasi dan tes. Data dianalisis dengan menggunakan analisis deskriptif uji-t, dan gain score. Hasil analisis inferensial dengan perhitungan uji-t tampak nilai signifikansi sebesar 0,001 dibandingkan dengan nilai $\alpha$ sebesar 0,05 atau 0,001 $<0,05$ yang berarti H0 ditolak dan H1 diterima. Hasil penelitian menunjukkan bahwa; (1) Media pembelajaran video pada model pembelajaran virtual, efektif digunakan pada proses pembelajaran mata kuliah Strategi Belajar Mengajar, (2) Terjadi peningkatan aktivitas belajar peserta didik dengan mengunakan media pembelajaran video pada pembelajaran Virtual, hal ini dapat dilihat dari hasil pengamatan pada kelompok A dan kelompok B.
\end{abstract}

Kata Kunci : Media pembelajaran Video, Model Pembelajaran Virtual, Efektivitas, Aktivitas belajar.

\section{PENDAHULUAN}

Pendidikan merupakan faktor penting dalam menentukan masa depan dan kelangsungan hidup suatu bangsa. Pendidikan dapat mendorong peningkatan kualitas hidup manusia. Menurut Feni (2014), pendidikan merupakan bimbingan yang diberikan oleh orang dewasa kepada perkembangan anak untuk mencapai kedewasaan dengan tujuan untuk melaksanakan tugas hidupnya sendiri tidak dengan bantuan orang lain. Pendidikan menghasilkan manusia yang bermanfaat bagi masyarakat dan negara baik secara intelektual, emosional, dan sprititual, seperti tercapainya tujuan negara tersebut pemerintah menyelenggarakan pendidikan nasional.

Berdasarkan Undang-undang No. 20 Tahun 2003 tentang Sistem Pendidikan Nasional Pasal 3 menyatakan bahwa pendidikan nasional berfungsi untuk mengembangkan kemampuan dan membentuk watak serta peradaban bangsa; bertujuan untuk menjadikan manusia yang beriman dan bertaqwa kepada Tuhan Yang Maha Esa, berakhlak mulia, sehat, berilmu, kreatif, mandiri, dan menjadi warga negara yang demokrasi, serta bertanggung jawab.

Komponen utama yang harus dipenuhi dalam proses belajar mengajar yaitu siswa, guru, tujuan pembelajaran, model, metode pembelajaran, media, dan evaluasi. Tujuan pembelajaran yang diinginkan tentunya yang optimal.Untuk itu, ada beberapa hal yang perlu diperhatikan oleh guru, salah satunya adalah model pembelajaran (Mangesa, R. T \& Mappaloteng, A. M, 2019).

Pada kondisi seperti ini semua tenaga pendidik dan peserta didik tidak lagi tepat pada saat ini akibat adanya pandemi covid 19 , untuk mengganti pembelajaran menggunakan E-learning atau melalui media pada model virtual. Pembelajaran virtual memberikan dampak positif yaitu pengalaman dan pemanfaatan teknologi dalam hal positif serta mewujudkan tantangan pendidik. Pembelajaran vitual membawa perubahan dalam sistem pendidikan, materi yang akan diajarkan, pembelajaran yang dilakukan serta hambatan-hambatan yang dihadapi baik oleh pendidik, peserta didik dan penyelanggara pendidikan.

Penggunaan model konvensional dalam pembelajaran tatap muka yang selama ini banyak dilakukan di perguruan tinggi, salah satunya Universitas Negeri Makassar (UNM), Jurusan Teknik Informatika dan Komputer, Prodi PTIK, sekarang tidak memungkinkan untuk dilakukan pembelajaran tata muka akibat pandemi covid 19 ini. Dalam hal ini, peserta didik dan pendidik harus mengikuti perkuliahan melalui pembelajaran virtual, pembelajaran tatap muka pun harus dialihkan secara virtual atau berbasis online. Adapun teknologi yang dapat dipakai guna mendukung pembelajaran virtual seperti aplikasi Zoom, Google Classroom, dan bisa juga bervariasi mulai dari radio, audio, video, voice, internet.

Pembelajaran virtual pada mata kuliah Strategi Belajar Mengajar merupakan mata kuliah wajib di Prodi PTIK JTIK menimbulkan suatu permasalahan karena pada hakikatnya Pembelajaran Strategi Belajar Mengajar adalah pembelajaran mampu menguasai teknik, model, metode, serta implementasi dalam pembelajarannya dan kejadian yang memerlukan observasi, hingga peserta didik harus diharuskan melihat apa yang dapat dipelajari. Pembelajaran virtual menimbulkan hambatan bagi peserta didik yang tidak mengerti sehingga mengalami kesulitan dalam belajar, selain itu Strategi Belajar Mengajar juga terdapat praktik yang bertujuan untuk lebih memperjelas cara mengajar yang dapat diamati secara langsung.

Hal ini untuk tetap melaksanakan proses pembelajaran, maka peneliti mengunakan media pembelajaran video pada model pembelajaran virtual, dengan menggunakan media video pembelajaran diharapkan peserta didik lebih aktif dan semangat belajar. Maka dari itu, para pendidik dapat membuat cara untuk menyampaikan bahan ajarnya yakni dengan menggunakan media pembelajaran video pada model pembelajaran virtual.

Media video pembelajaran merupakan media yang menyajikan audio dan visual yang berisi pesan-pesan pembelajaran baik yang berisi konsep, prinsip, prosedur, teori aplikasi pengetahuan untuk membantu pemahaman terhadap suatu materi pembelajaran.Berdasarkan latar belakang yang dipaparkan sebelumnya, penelitian penting dilakukan untuk mengetahui seberapa efektif media video pembelajaran pada model virtual pada mata kuliah Strategi Belajar Mengajar, Sehubungan dengan itu, peneliti bermaksud mengangkat penelitian yang berkenaan dengan 
masalah-masalah utama yang dihadapi oleh pendidik dengan judul "Efektivitas Media Pembelajaran video pada Model Pembelajaran Berbasis Virtual pada Mata Kuliah Strategi Belajar Mengajar di Prodi PTIK JTIK FT Universitas Negeri Makassar". Adapun rumusan masalah dalam penelitian ini sebagai berikut:

1. Apakah media pembelajaran video pada model pembelajaran virtual efektif digunakan pada mata kuliah Strategi Belajar Mengajar di Prodi PTIK JTIK Fakultas Teknik Universitas Negeri Makassar?

2. Apakah ada peningkatan aktivitas belajar peserta didik dalam media pembelajaran video pada model pembelajaran Virtual mata kuliah Strategi Belajar Mengajar di Prodi PTIK JTIK Fakultas Teknik Universitas Negeri Makassar?

\section{METODE PENELITIAN}

Jenis Penelitian

Jenis penelitian yang digunakan dalam penelitian ini adalah penelitian Quasi Eksperimen. Tujuan penelitian ini yakni untuk mengetahui keefektifan media pembelajaran video pada model pembelajaran virtual Mata kuliah Strategi Belajar Mengajar di Prodi PTIK JTIK FT Universitas Negeri Makassar.

Penelitian dilakukan dengan memberikan perlakuan (treatment) tertentu terhadap subjek penelitian yang bersangkutan dengan menggunakan desain eksperimen PretestPosttest Control Group Design

Waktu dan Lokasi Penelitian

Penelitian ini dilaksanakan mulai bulan Agustus sampai dengan September 2020. Adapun tempat penelitian ini dilaksanakan di Prodi PTIK JTIK FT Universitas Negeri Makassar, Kampus II Parangtambung Kota Makassar, Sulawesi Selatan.

Desain Penelitian

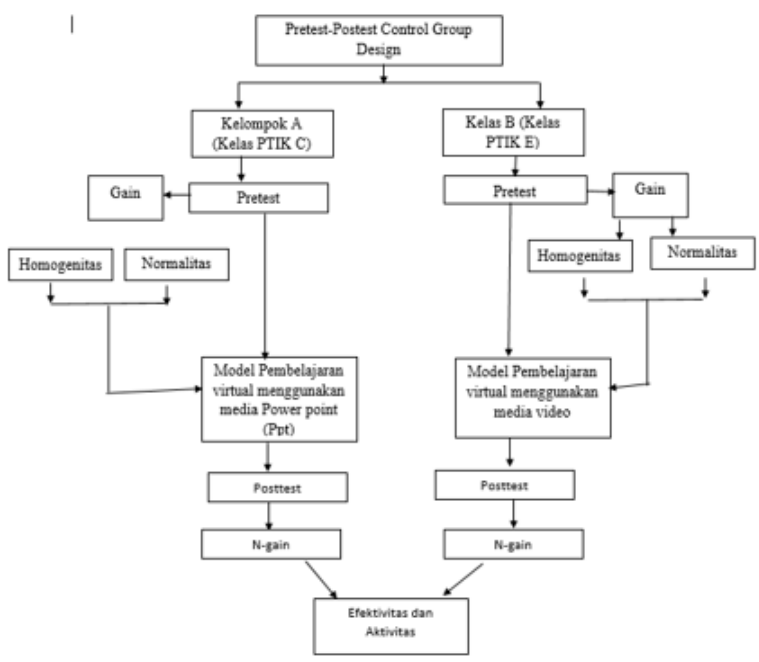

Gambar 1. Desain Penelitian

Penelitian dirancang pretest-posttest Control Group Design dibedakan atas kelompok A kelompok B. Pertama, dilakukan pretest masing-masing kelas kemudian dilakukan uji homogenitas dan normalitas. Hasil kedua uji tersebut pada masing- masing kelas menentukan apakah masing-masing kelompok dilakukan treatment atau tidak. Setelah dilakukan treatment pada masing-masing kelompok, yakni kelompok A dengan treatment Model pembelajaran berbsis virtual menggunakan media Power Point dan kelomok B dengan treatment model pembelajaran berbasis virtual menggunakan media video. Selanjutnya masing-masing dilakukan posttest. Nilai hasil posttest dihitung dengan nilai pretest untuk perhitungan skor Gain. Skor Gain ini akan menunjukkan gambaran perbedaan nilai baik Prestest maupun Posttest.

Populasi Dan Sampel

Populasi

Populasi penelitian ini adalah semua mahasiswa Prodi PTIK yang memprogramkan mata kuliah Strategi Belajar Mengajar tahun 2020 yang berjumlah 191 mahasiswa

Sampel

Sampel dalam penelitian ini yaitu kelas PTIK C dan kelas PTIK E yang memprogramkan mata kuliah Strategi Belajar Mengajar yang berjumlah 76 peserta didik. Penarikan sampel ini dilakukan dengan menggunakan teknik purposive sampling. Sampel sejumlah 76 peserta didik tersebut terdiri dari kelompok A dan kelompok B.

\section{Variabel Penelitian}

Variabel dalam penelitian ini, hanya menggunakan satu variabel namun hanya menggunakan 2 kelompok, Kelompook A (PTIK C) Kelompok B (PTIK E). Variabel bebas adalah efektivitas media pembelajaran video pada model pembelajaran virtual di Prodi PTIK JTIK FT Univeristas Negeri Makasar. Variabel terikat dalam penelitian ini adalah Efektivitas dan Aktifitas Belajar.

Teknik Pengumpulan Data dan Instrumen

Teknik pengumpulan data dan instrumen yang digunakan dalam penelitian ini meliputi :

\section{Observasi}

Lembar observasi digunakan untuk mengumpulkan data tentang aktivitas belajar selama kegiatan pembelajaran berlangsung pada dua kelompok A dan B yang dilakukan oleh dua pengamat

Tabel 1. Kisi-Kisi Lembar Observasi Aktivitas Peserta didik

\begin{tabular}{|c|l|c|c|}
\hline No & Indikator & Butir & $\begin{array}{l}\text { Jumlah } \\
\text { Butir }\end{array}$ \\
\hline 1 & $\begin{array}{l}\text { Menyimak atau mendengarkan } \\
2\end{array}$ & $\begin{array}{l}\text { Membelajaran } \\
\text { Mengajukan pertanyaan }\end{array}$ & 2 \\
\hline 3 & $\begin{array}{l}\text { Merespon arahan/berpartisipasi dalam } \\
\text { diskusi kelompok }\end{array}$ & $6,4,5$ & 3 \\
\hline 4 & Menyampaikan hasil diskusi atau individu & $\begin{array}{l}9,10,1 \\
1,12\end{array}$ & 4 \\
\hline
\end{tabular}

\section{Angket}

Bentuk angket yang digunakan adalah angket tertutup yakni angket yang sudah disediakan jawabannya. Angket diberikan setelah seluruh pelaksanaan proses pembelajaran telah selesai untuk melihat apakah media pembelajaran video dan powerpoint pada model Virtual diterima atau ditolak sebagai respon peserta didik

Tabel 2. Kisi-Kisi Instrumen Angket

\begin{tabular}{|c|l|c|c|}
\hline No & \multicolumn{1}{|c|}{ Indikator } & Butir & $\begin{array}{l}\text { Jumlah } \\
\text { Butir }\end{array}$ \\
\hline 1 & Cara belajar kelompok & $1,2,3$ & 3 \\
\hline 2 & Pemilihan materi ajar & $4,5,6$ & 3 \\
\hline 3 & $\begin{array}{l}\text { Melatih diri mampu berdiskusi } \\
\text { dengan baik }\end{array}$ & 7,8 & 2 \\
\hline 4 & Ketekunan menyelesaikan tugas & $\begin{array}{c}9, \\
10,11,12\end{array}$ & 4 \\
\hline 5 & Pemilihan Media & $13,14,15$ & 3 \\
\hline
\end{tabular}

3. Tes

Teknik pengumpulan data pertama yang digunakan adalah Tes. Tes dilakukan dua kali yaitu pre-test (tes awal) dan post-test (tes akhir). 
Tabel 3. Kisi-Kisi Instrumen Tes

\begin{tabular}{|c|c|c|c|c|}
\hline No & $\begin{array}{c}\text { Kompetensi } \\
\text { Dasar }\end{array}$ & Sub Pokok Bahasan & $\begin{array}{c}\text { Bentuk } \\
\text { Soal }\end{array}$ & $\begin{array}{l}\text { Nomor } \\
\text { Soal }\end{array}$ \\
\hline 1 & $\begin{array}{l}\text { Memahami konsep } \\
\text { dasar strategi } \\
\text { pembelajaran }\end{array}$ & $\begin{array}{l}\text { Pengertian strategi } \\
\text { pembelajaran, } \\
\text { Model, pendekatan, } \\
\text { metode, dan teknik } \\
\text { pembelajaran }\end{array}$ & $\begin{array}{l}\text { Pilihan } \\
\text { ganda }\end{array}$ & 1,2 , dan 3 \\
\hline 2 & $\begin{array}{l}\text { Memahami } \\
\text { komponen dasar } \\
\text { strategi } \\
\text { pembelajaran }\end{array}$ & $\begin{array}{l}\text { komponen strategi } \\
\text { pembelajaran }\end{array}$ & $\begin{array}{l}\text { Pilihan } \\
\text { ganda }\end{array}$ & 4 dan 5 \\
\hline 3 & $\begin{array}{l}\text { Menerapkan Jenis } \\
\text { dan metode belajar } \\
\text { mengajar }\end{array}$ & $\begin{array}{l}\text { Penerapan Strategi } \\
\text { Belajar Mengajar }\end{array}$ & $\begin{array}{l}\text { Pilihan } \\
\text { ganda }\end{array}$ & 6,7 dan 8 \\
\hline 4 & $\begin{array}{l}\text { Menganalis } \\
\text { penerapan } \\
\text { teoriteori belajar } \\
\text { dalam } \\
\text { pembelajaran. }\end{array}$ & $\begin{array}{l}\text { Mendikripsikan prinsip- } \\
\text { prinsip belajar dalam } \\
\text { pencapaian tujuan } \\
\text { pembelajaran. }\end{array}$ & $\begin{array}{l}\text { Pilihan } \\
\text { ganda }\end{array}$ & 9 dan 10 \\
\hline
\end{tabular}

4. Dokumentasi

Teknik dokumentasi digunakan dengan menyediakan dokumen-dokumen/ data sebagai bukti akurat yang mendukung dalam penelitian ini, meliputi data jumlah siswa, foto-foto yang diambil saat penelitian dan lain sebagainya.

\section{HASIL DAN PEMBAHASAN}

a. Uji Normalitas

1) Uji Normalitas Hasil Pretest dan Postest kelompok A

Uji normalitas yang digunakan dalam penelitian ini yakni metode perhitungan Kolmogrov-Smirnov dengan kriteria jika nilai signifikansi (sig).> 0,05, maka data dinyatakan berdistribusi normal Namun, jika nilai signifikansi (sig). $<0,05$, maka data dinyatakan tidak berdistribusi normal dengan hipotesis: $\mathrm{H0}$ : data berasal dari populasi yang berdistribusi normal; dan $\mathrm{H} 1$ : data tidak berasal dari populasi yang berdistribusi normal.

Tabel 4. Hasil Uji Normalitas pretest dan postest Kelompok A

\begin{tabular}{|c|c|c|c|c|}
\hline No & Data & Kolmogrov-Smirnov $Z$ & $\mathrm{~A}$ & $\mathrm{Sig}$ \\
\hline 1 & Pretest & 1,69 & 0,05 & 0,08 \\
\hline 2 & Postest & 155 & 0,05 & 0,12 \\
\hline
\end{tabular}

Berdasarkan hasil analisis uji normalitas dengan menggunakan program SPSS Versi 25 pada Tabel 4 dapat diketahui nilai signifikansi untuk pretest diperoleh nilai sig $=0,08>0,05$ sedangkan hasil uji normalitas Posttest diperoleh nilai sig $=0,12>0,05$. kedua nilai ini diuji menggunakan uji Kolmogrov-Smirnov Z.

2) Uji Normalitas Hasil Pretest dan Post-test Kelompok B

Tabel 5. Hasil Uji Normalitas pretest dan postest Kelompok B

\begin{tabular}{|l|c|c|c|c|}
\hline No & Data & Kolmogrov-Smirnov $\boldsymbol{Z}$ & $\mathbf{A}$ & Sig \\
\hline 1 & Pretest & 1,66 & 0,05 & 0,10 \\
\hline 2 & Postest & 164 & 0,05 & 0,21 \\
\hline
\end{tabular}

Berdasarkan Tabel 5, menunjukkan bahwa hasil uji normalitas pretest kelompok B diperoleh nilai Sig. $=0,10>0,05$ sedangkan hasil uji normalitas posttest diperoleh nilai Sig. $=0,21>0,05$. Hal ini menunjukkan bahwa data pretest dan posttest kelompok B memenuhi kriteria uji normalitas sehingga dapat disimpulkan berdistribusi normal.

b. Uji Homogenitas

Uji homogenitas yang digunakan dalam penelitian ini yakni metode perhitungan Test of Homogeneity of Variance dengan kriteria jika nilai signifikansi $>0,05$, maka data dinyatakan data bersifat homogen. Namun, jika nilai signifikansi<0,05, maka data dinyatakan tidak homogen dengan hipotesis: H0 : data bersifat homogen; dan $\mathrm{H} 1$ : data tidak homogen.

Tabel 6. Hasil Uji Homogenitas

\begin{tabular}{|c|c|c|c|c|}
\hline Aktivitas Belajar & Levene Statistic & Df & A & Sig \\
\hline Based on mean & 0,948 & 1 & 0.05 & 0,333 \\
\hline
\end{tabular}

Hasil analisis uji homogenitas menggunakan testof homogeneity of variances pada program SPSS Versi 25 pada Tabel 6, menunjukkan nilai signifikansi based of meansebesar 0,333. Berdasarkan kriteria data yang bersifat homogen, hal tersebut menunjukkan bahwa nilai signifikansi lebih besar dari $0,05(0,333>$ $0,05)$.

c. Uji Hipotesis

1) Hipotesis nol $(\mathrm{H} 0)$ : tidak terdapat peningkatan yang signifikan pada kelompok A dalam media pembelajaran powerpoint pada pembelajaran virtual mata kuliah Strategi Belajar Mengajar di Prodi PTIK.

2) Hipotesis alternatif (H1) : terdapat peningkatan hasil yang signifikan pada kelompok $\mathrm{B}$ yang menggunakan media pembelajaran video pada model pembelajaran virtual mata kuliah Strategi Belajar Mengajar di prodi PTIK.

Berikut adalah hasil independent sample t-test dengan SPSS Versi 25.

Tabel 7. Independent Sample T-Test

\begin{tabular}{|c|c|c|c|c|c|}
\hline \multirow{2}{*}{ Postest } & F & Sig. & t & Df & Sig.(2-tailed) \\
\cline { 2 - 6 } & 2,395 & 0,126 & $-9,996$ & 74 & 0,0001 \\
\hline
\end{tabular}

Berdasarkan tabel 7 diperoleh harga t hitung $=-9,996$ dan nilai sig. $=0,0001$ karena sig $<\alpha$ yaitu $0,0001<0,05$, dengan demikian Ho ditolak dan $\mathrm{H} 1$ diterima.

1. Analisis Keefektifan Model pembelajaran berbasis Virtual Tabel 8. Analisis N-Gain Pada Kelompok A

\begin{tabular}{|c|c|c|c|c|c|}
\hline \multirow{2}{*}{$\begin{array}{c}\text { N-Gain } \\
\text { Persen }\end{array}$} & Kelompok A & Maximun & Minimum & Statistic & Std. Error \\
\cline { 2 - 6 } & Mean & 60,00 & $-33,33$ & 19.3421 & 2.98767 \\
\hline
\end{tabular}

Berdasarkan Tabel tersebut, hasil perhitungan uji N-Gain skor menunjukkan bahwa nilai rata-rata N-gain skor untuk kelompok $\mathrm{A}$ adalah sebesar 19,3421 atau 19,34\%.

Tabel 9. Analisis N-Gain Pada Kelompok B

\begin{tabular}{|c|c|c|c|c|c|}
\hline \multirow{2}{*}{ N-Gain } & Kelompok B & Maximun & Minimum & Statistic & Std. Error \\
\cline { 2 - 6 } & Mean & 100,00 & 0 & 57.6253 & 4.88910 \\
\hline
\end{tabular}

Berdasarkan hasil perhitungan uji N-Gain skor tersebut, menunjukkan bahwa nilai rata-rata $\mathrm{N}$-gain skor untuk kelompok $\mathrm{B}$ adalah sebesar 57,6253 atau 57,62\% termasuk dalam kategori efektif.

2. Peningkatan Aktivitas Peserta Didik

a. Peningkatan Aktivitas Observasi Kelompok A

Tabel 10. Aktivitas Observasi Kelompok A

\begin{tabular}{|c|c|c|c|c|}
\hline No & Pengamat 1 & Pengamat 2 & Rata-rata & Kategori \\
\hline 1 & $50 \%$ & $25 \%$ & $37,5 \%$ & Sangat Tinggi \\
\hline 2 & $41,67 \%$ & $41,67 \%$ & $41,67 \%$ & Tinggi \\
\hline 3 & $8,3 \%$ & $25 \%$ & $20,81 \%$ & Sedang \\
\hline 4 & $0 \%$ & $8,3 \%$ & $4,15 \%$ & Rendah \\
\hline 5 & $0 \%$ & $0 \%$ & $0 \%$ & Sangat Rendah \\
\hline
\end{tabular}

Sumber : Hasil Olah Data observasi Aktivitas 


\section{b. Peningkatan Aktivasi Observasi Kelompok B}

Tabel 11. Aktivitas Observasi Kelompok B

\begin{tabular}{|c|c|c|c|c|}
\hline No & Pengamat 1 & Pengamat 2 & Rata-rata & Kategori \\
\hline 1 & $58,3 \%$ & $8,3 \%$ & $33,3 \%$ & Sangat Tinggi \\
\hline 2 & $41,67 \%$ & $66,67 \%$ & $54,13 \%$ & Tinggi \\
\hline 3 & $0 \%$ & $25 \%$ & $12,5 \%$ & Sedang \\
\hline 4 & $0 \%$ & $0 \%$ & $0 \%$ & Rendah \\
\hline 5 & $0 \%$ & $0 \%$ & $0 \%$ & Sangat Rendah \\
\hline
\end{tabular}

Sumber : Hasil Olah Data observasi Aktivitas

Berdasarkan kedua Tabel di atas pada peningkatan aktivitas observasi aktivitas belajar peserta didik pada mata kuliah Strategi Belajar Mengajar, terjadi peningkatan pada model pembelajaran Virtual dengan media pembelajaran video pada kelompok B dengan rata-rata $54,13 \%$. Kemudian model pembelajaran Virtual dengan media pembelajaran Power point di peroleh rata-rata 41,67 \% pada kelompok A. Hal ini media pembelajaran video pada model pembelajaran virtual meningkat di bandingakan model pembelajaran berbasis virtual dengan Power point pada mata kuliah Strategi Belajar Mengajar di Prodi JTIK FT Universitas Negeri Makassar.

\section{Pembahasan}

Pada Media pembelajaran video pada model pembelajaran virtual mata kuliah Strategi Belajar Mengajar di Prodi JTIK FT Universitas Negeri Makassar, penelitian ini dilaksanakan dalam virtual agar penelitian ini dapat terlaksana, di mana pada pembelajaran dilakukan dua kelompok yakni kelompok A (kelas PTIK C) dengan media pembelaajaran Powerpoint dan kelompok B (Kelas E) media pembelajaran video melalui gogle classroom dan google meet. Berdasarkan hasil penelitian sebelum diberikan perlakuan, nilai rata-rata pretest aktivitas belajar untuk kelas kelompok A yaitu sebesar 51,57 dan untuk kelompok B sebesar 60,26 , kemudian setelah diberi perlakuan nilai rata-rata postest aktivitas belajar Startegi Belajar Mengajar untuk kelompok A yaitu 61,84 dan untuk kelompok B sebesar 85,26. Jadi, dapat disimpulkan bahwa terjadi peningkatan rata-rata belajar peserta didik kelompok B yang diajar dengan menggunakan media pembelajaran video pada model pembelajaran virtual. Aktivitas belajar Startegi Belajar Mengajar peserta didik yang diajar menggunakan media pembelajaran video lebih tinggi dibandingkan dengan peserta didik yang diajarkan menggunakan media pembelajaran Ppt pembelajaran artinya lebih meningkat yang menggunakan media pembelajaran video. Hal ini desebabkan karena model pembelajaran berbasis virtual menggunakan media pembelajaran video peserta didik lebih mengerti dan didukung oleh penerapan video pembelajaran yang cukup menarik perhatian peserta didik.

Berdasarkan hasil uji hipotesis dengan menggunakan uji-t, diperoleh nilai signifikan(2-tailed) sebesar 0,000 dengan nilai signifikansi yang digunakan 0,05 . Karena sig. $<a$ yaitu $0,000<0,005$ dengan $\mathrm{H}_{0}$ ditolak dengan $\mathrm{H}_{1}$ diterima, sehingga dapat disimpulkan bahwa terdapat perbedaan rata-rata aktivitas belajar Strategi Belajar Mengajar antara peserta didik yang diajar dengan menggunakan media ppt dengan yang diajar menggunakan media video pembelajaran

Perhitungan uji N-Gain skor menunjukkan bahwa nilai rata-rata N-gain skor untuk kelompok A adalah sebesar 19,3421 atau $19,34 \%$. Skor ini termasuk dalam kategori kurang efektif. Ketidakefektifan ini disebabkan peserta didik bosan belajar karena media kurang menarik, kemudian nilai rata-rata $\mathrm{N}$-gain untuk kelompok B adalah sebesar 57,6253 atau 57,62\%.

\section{KESIMPULAN DAN SARAN}

Kesimpulan

Berdasarkan hasil penelitian dan pembahasan, berikut ini beberapa simpulan mengenai penelitian "Efektivitas Media Pembelajaran video pada model pembelajaran Virtual mata kuliah Strategi Belajar Mengajar di Prodi PTIK JTIK FT Universitas Negeri Makassar";

1. Penerapan media pembelajaran video pada model pembelajaran virtual efektif karena Model pembelajaran berbasis virtual dengan media video meningkat dipergunakan pada mata kuliah Strategi Belajar Mengajar di Prodi PTIK JTIK Fakultas Teknik Universitas Negeri Makassar. Hal ini berdasarkan Hasil belajar pada kedua kelompok diperoleh nilai Posttest rata-rata 61,84\% pada kelompok A, sedangkan nilai Posttets kelompok B diperoleh rata-rata $85,26 \%$. Dan hasil perhitungan SPSS 25 yang menunjukkan nilai Asymp.Sig.(2-,tailed) sebesar 0,001 dibandingkan dengan probabilitas sebesar 0,05 atau sig. $<\alpha$ $(0,0001<0,005)$. Data tersebut menandakan bahwa H1 diterima dan HO ditolak. Hasil yang sama pun diperoleh jika diukur dari nilai p-value, yang bernilai 0,0001 lebih kecil dari nilai 0,05 ( $\mathrm{p}$-value $<0,05$ ).

2. Aktivitas media pembelajaran video pada model pembelajaran Virtual mata Kuliah Strategi Belajar Mengajar di Prodi PTIK JTIK FT Universitas Negeri Makassar mengalami peningkatan, dimana pada model pembelajaran berbasis virtual dengan media video lebih meningkat dari pada pembelajaran menggunakan media Powerpoint dengan rata-rata skor 44,67\% dan hasil pada kelompok B diperoleh rata-rata $54,13 \%$. Sedangkang respon peserta didik pada kelompok A diperoleh persentase rata-rata sebesar 2,6\% dalam kategori sangat baik dan kelompok kelompok $\mathrm{B}$ diperoleh persentase rata-rata sebesar 78,9 \%, dalam kategori sangat baik maka dapat disimpulkan bahwa model pembelajaran berbasis virtual pada mata kuliah Strategi Belajar Mengajar mengalami peningkatan dengan media video pembelajaran pada mata kuliah Strategi Belajar Mengajar di Prodi PTIK JTIK FT Universitas Negeri Makassar.

Saran

Berikut ini beberapa saran yang diajukan berkaitan dengan penelitian ini.t;

1. Hendaknya pembelajaran berbasis virtual didukung adanya sarana dan prasarana, baik pendidik maupun peserta didik, seperti akses internet yang memadai.

2. Hendaknya peserta didik menempatkan diri dikawasan yang memiliki koneksi jaringan yang memadai

3. Hendaknya pendidik memberikan arahan dengan baik kepada peserta didik agar penyampaian informasi pembelajaran mudah dipahami oleh peserta didik karena kondisi pembelajaran virtual sangat berbeda dengan kondisi pembelajaran tata muka

4. Hendaknya pendidik menggunakan sarana pembelajaran yang mudah diakses oleh peserta didik, misalnya penggunaan aplikasi google meet dibandingkan dengan aplikasi lainnya.

5. Hendaknya pendidik juga menambahkan media pembelajaran guna menunjang proses pembelajaran.

\section{DAFTAR PUSTAKA}

[1] Abdurahmat 2003."Efektifitas Pembelajaran". http://koleksi.org/pengertian-efektifitas- menurut-para-ahli. 12 Maret 2011. Diakases pada tanggal 25 Novomber 2020

[2] Afifatu Rohmawati, 2015 "Efektivitas Pembelajaran: dalam Jurnal Pendidikan Usia Dini, (Jakarta: dan Penerbit Universitas Negri Jakarta), No. 9/Edisi 1, April 2015.

[3] Agustin, M. 2016"Problem Base Learning (Pbl) : Suatu Model Pembelajaran Untuk Mengembangkan Cara Berpikir Kreatif Siswa”. Diakses pada tanggl 27 November 2020 
file:///C:/Users/ASUS/Downloads/173-25-257-1-1020190120.pdf

[4] Darmalaksana, Hambali, Masrur, \& Muhlas, 2020. Analisis Pembelajaran Online Masa WFH Pandemic Covid-19 sebagai Tantangan Pemimpin Digital Abad 21

[5] D.Kenneth,Moh Syarif. 2015. Pembelajaran Efektif (Terjemahan). Jakarta: Grasindo.

[6] Kemendikbud, 2020.Pelaksanaan Pendidikan Dalam Masa 3 Darurat Covid-19' https://www.kemdikbud.go.id/main/blog/2020/03/semendikbud-pelaksanaan-kebijakan-pendidikan-dalam-masadarurat-penyebaran-covid19. Diakses Pada tangal 4 Februari 202

[7] Mangesa, R. T., \& Mappaloteng, A. M. 2019. Mengoptimalkan kualitas proses pembelajaran melalui pembelajaran kooperatif dengan Penelitian Tindakan Kelas. Jurnal Seminar Nasional Pengabdian Kepada Masyarakat. (Di akses pada tanggal 26 Januari 2020).

[8] Mangesa, R.T. 2020. "Berbagai Jenis Strategi Pembelajaran"

[9] Munir.2012. Pembelajaran Jarak Jauh, (Bandung: Alfabet2012)

[10] Nana, Rahardjo. 2011. "Efektivitas E-learning Sebagai Media Pembelajaran Mata Pelajaran TIK Kelas XI di SMA Negeri Depok. Yogyakarta: UNY.

[11] Oemar, Hamalik. 2005. Kurikulum dan Pembelajaran. Bandung: Bumi Aksara.

[12] Oktaviani,H dan dkk .2020. Model Pendekatan Pembelajaran Virtual di MI Ma'arif NU Limbangan. Institut Agama Islam Imam Al Ghazali, Cilacap, Indonesia.

[13] Paja R. 2017. "Keefektifan Pembelajaran Matematika Dengan Menerapkan Kombinasi Model Cooperative Learning Tipe Make A Match Dan Discovery Learning Pada Peserta Didik Kelas Vii Smp Negeri 2 Parepare". Artikel.UNM

[14] Pupuh Fathurrohman, M. Sobry Sutikno. 2017. Strategi Belajar Mengajar Melalui Penanaman Konsep Umum \& Konsep Islami, (Jakarta: PT. Refika Aditama).

[15] Putu Budi Adnyana 2014. Pengaruh Model pembelajaran Berbasis Proyek terhadap Aktivitas belajar Biologi Ditinjau dari Gaya belajar Siswa SMA. Singaraja: Jurnal Penelitian Pascasarjana undiksha.

[16] Risnawati. (2018)."Efektivitas penerapan model pembelajaran student facilitator and explaining terhadap aktivitas belajar matematika siswa kelas vii smp negeri 1 tarowang kabupaten jeneponto”.Skripsi :Univeritas Islam Alauddin Makassar.

[17] Rohmawati, Afifatu. 2015. "Efektivitas Pembelajaran". Jurnal Pendidikan Usia Dini. Vol. 9, Ed. 1, April 2015.

[18] Rusman, 2019. Rusman, 2012. Model-model Pembelajaran: Mengembangkan Profesionalisme Guru, RajaGrafindo Persada, Jakarta

[19] Sudjana. 2000. Dasar- Dasar Proses Belajar Mengajar. Bandung: Sinar Baru Algensindo.

[20] Sudjana, Nana. 2011. Dasar-Dasar Proses Belajar Mengajar. Bandung: Sinar Baru Algosindo.

[21] Suharsimi, A., Suhardjono., Supardi. 2015. "Penelitian Tindakan Kelas". Jakarta: PT. Bumi Aksara.

[22] Sugiyono. 2010. Statistika Untuk Penelitian. Bandung: Alfabeta.

[23] Sujarweni, Wiratna.V. 2014. Metodologi Penelitian. Yogyakarta: Pustaka Baru Press.

[24] Syaiful Bahri.D, Adi 2006. "Strategi Belajar Mengajar". Jakarta : PT Rineka CiptaWena.
[25] Thobrani \& Arif Mustofa. 2011. "Belajar dan Pembelajaran". Yogyakarta:Deaken Univercity Press.

[26] Trianto. 2011. Model Pembelajaran Terpadu. Jakarta: Bumi Aksara.

[27] UU RI NO. 20 Tahun 2003. "Sistem Pendidikan Nasional 8 Juli 2003 Lembaran Negara Republik Indonesia Tahun 2003 Nomor 4301. Jakarta. (Online). Tersedia pada: https://kemenag.go.id/file/dokumen/UU2003.pdf. Diakses tanggal 10 Maret 2020.

[28] Wahab, Ali .2008 Tujuan Penerapan Program, Jakarta: Bulan Bintang.

[29] Wilson, M., Smaldino, S., Albright, M., \& Zvacek, S. (2001). Teaching and Learning at a Distance: Foundations of Distance Education (2nd Ed.). New Jersey: Merill Prentice Hall 